\title{
IN THE PROCEDURAL SURROUNDINGS OF CONSUMER PROTECTION: ONLINE DISPUTE RESOLUTION, THE ADVERSARIAL PRINCIPLE, AND TENDENCIES TOWARD SETTLEMENT*
}

by

ERIK BJÖRLING**

The article builds on a pluralistic perspective on law and the understanding that legal research must take into account the procedural and institutional landscape where legal rights are enforced. In relation to online dispute resolution (ODR), two procedural mechanisms, namely the adversarial principle and the tendency toward settlements, are studied and discussed. The adversarial principle (argued to be integral to most ODR procedures) and tendencies toward settlements (also argued to be integral to most $O D R$ procedures) are considered in relation to the overarching (and possibly contradictory) objectives of protecting individual consumer rights and the interest of increasing economic efficiency within the EU's internal market.

\section{KEY WORDS}

ADR, Adversarial Principle, Consumer Litigation, ODR, Procedural Law, Settlements

\section{INTRODUCTION}

Within European consumer law, the European Commission has been working actively for a number of years to resolve disputes in consumer cases through alternative dispute resolution formats. The efforts have been based on the key words simplicity, proportionality, justice, and efficiency, and

\footnotetext{
* The author would like to thank Ragnars Söderbergs stiftelse for making this article possible.

* erik.bjorling@law.gu.se, Erik Björling (LLD) is a researcher and teacher in the fields of procedural law and legal theory at the Department of Law, University of Gothenburg, Sweden.
} 
the method is alternative dispute resolution ( $A D R$ ), and in a digital setting online dispute resolution (ODR). ${ }^{1}$ The sector in which ODR is expected to have an impact is immense. In the EU, consumer transactions account for more than 50 percent of the total gross domestic product. ${ }^{2}$ About half of all EU consumers regularly shop over the Internet, and online sales are also the fastest growing type of sales in the EU. ${ }^{3}$

The most common legal conflicts related to consumer trade are what most people consider everyday legal types of conflicts such as delivery delays, damaged products, and products that do not arrive at all. ${ }^{4}$ Dispute resolution in consumer-related disputes, both through court and alternative processes, however, is anything but an everyday issue. Rather, consumer processes are unusual and only two percent of all EU consumers who believe they have a reason to target a business continue on to some type of dispute resolution procedure. Studies show that even companies are cautious about using the court as a forum for consumer disputes. ${ }^{5}$ Thus, there is a widespread reluctance to take conflicts that arise as a result of consumer consumption to judicial institutions. For disputes of lesser value, procedures that require the parties to meet face to face are simply not an option, especially in cross-border situations. ${ }^{6}$ In addition, the methods of ordinary dispute resolution are quite varied and, in most cases, very cumbersome. ${ }^{7}$

Consumer protection within the EU is ensured by means of mandatory rules that strengthen the position of the consumer. Signals from among others the Court of Justice of the European Union (CJEU) indicate that these

Cortés, P. (2017a) The Law of Consumer Redress in an Evolving Digital Market: Upgrading from Alternative to Online Dispute Resolution. Cambridge: Cambridge University Press, p. viii.

2 European Commission. (2012) Communication from the commission to the European Parliament, The Council, The Economic and Social Committee and the Committee of the Regions: A European consumer agenda- Boosting confidence and growth. $\operatorname{COM}(2012) 225$ final, p. 1.

3 Cortés, P. (2017a) The Law of Consumer Redress in an Evolving Digital Market: Uppgrading from Alternative to Online Dispute Resolution. Cambridge: Cambridge University Press, p. 4-5.

4 Ibid.

5 European Commission. (2011) Commission Staff Working Paper Impact Assessment Accompanying the document Proposal for a Directive of the European Parliament and of the Council on Alternative Dispute Resolution for consumer disputes (Directive on consumer ADR) and Proposal for a Regulation of the European Parliament and of the Council on Online Dispute Resolution for consumer disputes (Regulation on consumer ODR). SEC(2011) 1408 final, p. 13.

6 Cortés, P. (2017a) The Law of Consumer Redress in an Evolving Digital Market: Upgrading from Alternative to Online Dispute Resolution. Cambridge: Cambridge University Press, p. 2-4.

7 Commission staff working paper, p. 13. 
rights are to be upheld ex officio by court officials across the EU. ${ }^{8}$ However, since a very low number of conflicts between consumers and companies reach court proceedings, there is no forum, i.e. no institutional context, for actual enforcement of consumer protection. This is where the ADR and ODR initiatives are supposed to present an option. To enable easily accessible and efficient out-of-court redress for consumer disputes, including disputes arising from cross-border e-commerce, an extensive legal framework on ADR and ODR was adopted at EU level in 2013 and has been in place since 2016. The ODR as an initiative has its origin in the notion that civil courts for many years have failed to provide access to justice for ordinary individuals. ${ }^{9}$ The idea behind the initiative is to give consumers access to a comprehensive landscape of ADR bodies. By doing this the Commission is hopeful that consumers will be able to solve disputes with companies that arise from online transactions in a simple, fast, and inexpensive way, while companies avoid costly litigation procedures and maintain good customer relations. In addition to this, it is also outspoken that ODR considers the interest of increasing economic efficiency within the internal market. ${ }^{10}$ The importance of the ODR framework as a contributor to economic growth has been manifestly held forth by the Commission. ${ }^{11}$

The two legislative instruments comprising the described framework, the ADR Directive and the ODR Regulation, are interlinked and complementary. ${ }^{12}$ The online dispute resolution platform (the ODR

8 See, e.g. Judgement of 27 June 2000, Joined Cases Océano Grupo Editorial SA v Roció Murciano Quintero and Salvat Editores SA v José M. Sánchez Alcón Prades and Others, C-240/98 to C-244/98, ECLI:EU:C:2000:346, and Judgement of 4 June 2009, Pannon GSM Zrt. v Erzsébet Sustikné Győrfi, C-243/08, ECLI:EU:C:2009:350.

9 Cortés makes this point referring to Lord Justice Briggs. See Cortés, P. (2017b) The Online Court: Filling the Gaps of the Civil Justice System? Civil Justice Quarterly, 36, pp. 109-126, p. 109.

10 Cortés, P. (2017a) The Law of Consumer Redress in an Evolving Digital Market: Upgrading from Alternative to Online Dispute Resolution. Cambridge: Cambridge University Press, p. 2. The ODR platform is supposed to contribute to strengthening consumers' and companies' confidence in shopping and trading online both in their country and abroad.

11 European Commission. (2012) Communication from the commission to the European Parliament, The Council, The Economic and Social Committee and the Committee of the Regions: A European consumer agenda- Boosting confidence and growth. $\operatorname{COM}(2012) 225$ final, p. 1.

12 Directive 2013/11/EU of the European Parliament and of the Council of 21 May 2013 on alternative dispute resolution for consumer disputes and amending Regulation (EC) No 2006/2004 and Directive 2009/22/EC (Directive on consumer ADR), Regulation (EU) No 524/2013 of the European Parliament and of the Council of 21 May 2013 on online dispute resolution for consumer disputes and amending Regulation (EC) No 2006/2004 and Directive 2009/22/EC (Regulation on consumer ODR) (2013). 
platform) - a website that channels complaints to ADR bodies - is the central node for the out-of-court framework that has been established. These ADR bodies (sometimes ODR entities) have been notified to the Commission by national authorities and must pass an assessment of their compliance with the quality requirements mandated in the ADR/ODR legal framework. $^{13}$ A large number of ADR bodies have been registered on the ODR platform since its launch. More than 300 ADR bodies from 26 member states can currently be accessed through the platform. The ADR bodies are complemented with designated national ODR contact points where consumers can receive assistance with how to use the platform. ${ }^{14}$

In light of the current reforms, a reasonable question to ask is how the objective of creating "easily accessible and efficient out-of-court redress" relates to other important principles and institutional considerations within the field of consumer redress. The present article focuses on procedural considerations regarding ODR. In order to understand the consequences of the ADR and ODR initiatives, there is a need for an assessment that includes the procedural mechanisms that contribute to the enforcement of the legal norms at stake. This article will discuss two such mechanisms, namely the adversarial principle and the tendency toward settlements. The aim is to address how the adversarial principle (argued to be integral to most ODR procedures) and tendencies toward settlements (also argued to be integral to most ODR procedures) affect the overarching idea of ODR as a tool to enforce consumer legislation. The article does not strive to criticize the system as such or to present ideas for reforms, but rather attempts to explore the procedural landscape where consumer redress is currently prioritized.

The institutional context where ODR takes place could be described as pluralistic. ODR exists in an institutional environment with public and private bodies (some of which are profit driven) that utilize a variety of techniques including meditation, arbitration, and ombudsman. ${ }^{15}$ In addition, there are different levels of technology (sometimes including advanced automated and assisted negotiation) involved in the digital

13 European Commission. (2017) Report from the Commission to the European Parliament and the Council on the functioning of the European Online Dispute Resolution platform established under Regulation (EU) No 524/2013 on online dispute resolution for consumer disputes COM(2017) 744 final, (2017) p. 1.

14 Op. cit., p. 4.

15 Schlote, J. A. (2017) Polycentrism and Democracy in Internet Governance. In: Uta Kohl (ed.). The Net and the Nation State. Cambridge: Cambridge University Press, pp. 165-184, p. 167. 
interfaces available through the ODR platform. ${ }^{16}$ Following the by now old idea that pluralism in fact should be followed by pluralism in norm/theory, this article takes its point of departure in pluralistic legal theory, which will be presented below. ${ }^{17}$

Discussions concerning tendencies toward settlements (and critique thereof) as well as discussions on the consequences of the adversarial principle, within different kinds of litigation, are certainly not new. Arguments and concerns about settlements in legal settings have already been put forth within the field of ODR. ${ }^{18}$ Also the adversarial principle have been discussed previously, at least considering the broader subject of ADR. ${ }^{19}$ However, as already mentioned, the aim of this article is not to critique these concepts, or the ODR platform or different ODR entities, per se. Instead, the article is rooted in the idea that in order to understand consumer litigation within the ODR framework, there is a need for theory and research concerning the institutional and procedural context of the ODR platform. The article aims at contributing to this by addressing how the adversarial principle and settlements affect the underlying landscape of consumer litigation through ODR.

The overarching aim of the article will be fulfilled by examining two ODR platforms in more detail, the German ODR entity General Consumer Arbitration Board, Center for Mediation (Allgemeine Verbraucher-schlichtungsstelle Zentrum für Schlichtung, AVZS) and the Swedish ODR entity National Board for Consumer Disputes (Allmänna reklamationsnämnden, $A R N)$. These ODR entities have been chosen as both of them deal with a large number of cases every year and because they have a quite similar (prima facie) internal structure. They will be use in order to illustrate how the adversarial principle (and below, the tendencies toward settlement) forms an integral part of the ODR entities and co-produces the outcome of the proceedings. The two ODR bodies are similar in most regards. However, for $\mathrm{ARN}$, the main rule is that the Board gives a proposal

16 Cortés, P. (2017a) The Law of Consumer Redress in an Evolving Digital Market: Upgrading from Alternative to Online Dispute Resolution. Cambridge: Cambridge University Press, p. 44-52.

17 Rosenfeld, M. (1998) Just interpretations: Law between ethics and politics. Santa Monica: University of California Press, 1998, p. 200.

18 See Eidenmüller, H. and Engel, M. (2014) Against False Settlement: Designing Efficient Consumer Rights Enforcement Systems in Europe. Ohio State Journal on Dispute Resolution, 29 (2), p. 261-298.

19 See, e.g. Wagner, G. (2014) Private Law Enforcement Through ADR: Wonder Drug Or Snake Oil. Common Market Law Review, 5, p. 165-194. 
to the parties and settlement is an exception to this rule. For AVZS, it is the other way around.

\section{CONSUMER ODR AND CONSUMER PROTECTION WITHIN THE EU}

Before moving on to the theoretical foundation for this article and the substantial discussions on the adversarial principle and settlements, a few words should be said about consumer protection in EU countries. Consumer legislation has been a priority for many decades within the EU. Article 169 (1) and subsection (a) of Article 169 (2) of the Treaty on the Functioning of the European Union (TFEU) provide that the Union is to contribute to the attainment of a high level of consumer protection through measures adopted pursuant to Article 114 TFEU. Similarly, Article 38 of the Charter of Fundamental Rights of the European Union provides that Union policies are to ensure a high level of consumer protection. In accordance with Article 26 (2) TFEU, the internal market is to comprise an area without internal frontiers in which the free movement of goods and services is ensured. The internal market should provide consumers with added value in the form of better quality, greater variety, reasonable prices, and high safety standards for goods and services, which should promote a high level of consumer protection. ${ }^{20}$

Consumer protection is highlighted in the first paragraphs of the ADR Directive and the ODR Regulation. These provisions state that the purpose of the Directive and the Regulation is to achieve a high level of consumer protection and to contribute to the proper functioning of the internal market. $^{21}$ According to the preamble of the ADR Directive, resolutions emanating from ADR (including ODR) should not result in a consumer being

20 European Commission. (2012) Communication from the commission to the European Parliament, The Council, The Economic and Social Committee and the Committee of the Regions: A European consumer agenda- Boosting confidence and growth. $\operatorname{COM}(2012) 225$ final, p. 2.

21 Directive 2013/11/EU of the European Parliament and of the Council of 21 May 2013 on alternative dispute resolution for consumer disputes and amending Regulation (EC) No 2006/2004 and Directive 2009/22/EC (Directive on consumer ADR). And Regulation, 'Regulation (EU) No 524/2013 of the European Parliament and of the Council of 21 May 2013 on online dispute resolution for consumer disputes and amending Regulation (EC) No 2006/2004 and Directive 2009/22/EC (Regulation on consumer ODR). 
"deprived of the protection afforded to him by the provisions that cannot be derogated from by agreement by virtue of the law of the Member State in which the consumer is habitually resident." 22

Furthermore, the rights to an effective remedy and to a fair trial are fundamental rights laid down in Article 47 of the Charter of Fundamental Rights of the European Union. Therefore, ADR procedures should not be designed to replace court procedures and should not deprive consumers or businesses of their rights to seek redress before the courts. In cases where a dispute could not be resolved through a given ADR procedure whose outcome is not binding, the parties should subsequently not be prevented from initiating judicial proceedings in relation to that dispute. ${ }^{23}$

The protection of consumer rights in relation to national procedural institutions has been discussed by the CJEU in several cases, with the clear signal that national courts should play an active part in protecting consumer rights. ${ }^{24}$ The cases are not specifically concerned with ODR entities, but are quite relevant to the field since they deal with the effective protection of consumers redress through national institutions. In cases such as Océano, Mostaza Claro, and Pannon, the CJEU stated that unfair prorogation clauses must be set aside by the court regardless of whether this is argued by the consumer and that national courts should make ex officio efforts to guarantee consumer rights. ${ }^{25}$ In Duarte Hueros, the CJEU held that a consumer not getting a price reduction constituted an infringement of the principle of effectiveness, even though the consumer had not claimed a price reduction in the court process. ${ }^{26}$ In Pénzügyi Lízing, the CJEU considered it a responsibility of the national court to take an active part in investigating whether consumer rights have been violated. ${ }^{27}$

22 Directive on consumer ADR, preamble $\S 44$.

23 Directive on consumer ADR, preamble $\S 45$.

${ }^{24}$ For deeper analysis on this matter see, e.g. [forthcoming] Wallerman, A. (2019) Manoeuvring Procedural Autonomy In Sweden: Is Materielle Prozessleitung the Answer? In: Anna Nylund and Bart Krans (ed.). Procedural autonomy: Room for manoeuvre? Cambridge: Intersentia.

25 Judgement of 27 June 2000, Joined Cases,Océano Grupo Editorial SA v Roció Murciano Quintero and Salvat Editores SA v José M. Sánchez Alcón Prades and Others, C-240/98 to C-244/98, ECLI:EU:C:2000:346, Judgement of 26 October 2006, Mostaza Claro v Centro Móvil Milenium SL, C-168/05, ECLI:EU:C:2006:675 and Judgement of 4 June 2009, Pannon GSM Zrt. v Erzsébet Sustikné Gyórfi, C-243/08, ECLI:EU:C:2009:350.

${ }^{26}$ Judgement of 3 October 2013, Soledad Duarte Hueros v Autociba SA och Automóviles Citroën España SA, C-32/12, ECLI:EU:C:2013:637.

27 Judgement of 6 July 2010, VB Pénzügyi Lizing Zrt. v Ferenc Schneider, C-137/08, ECLI:EU:C: 2010:659. 
The case law presented here indicates a strong responsibility for national institutions to act ex officio. Nevertheless, the CJEU has also highlighted the importance of ADR. In the Alassini case, where Italian legislation demanded that the consumer tried an out-of-court procedure before turning to a court, the CJEU approved of such a legislation, insofar as it ensures that out-of-court procedures are systematically used for settling disputes, and since it is designed to strengthen the EU consumer legislation at stake. ${ }^{28}$ In sum, the CJEU stresses the importance of national procedural law strengthening the position of the consumer but also seems to be open to this being done through ADR proceedings (e.g. via the ODR platform).

\section{PLURALISM AS A THEORETICAL TOOL FOR ODR RESEARCH}

Legal pluralism as a theoretical concept has many dimensions, which in turn can be said to target different aspects of ODR.

Firstly, pluralism comes with a theoretical baggage. To get a grasp of the theories behind pluralism, the following words by Davis are illustrative:

"All normativity is produced by interactions between human agents who are not abstract individuals with unattached free wills, but rather already situated in diverse contexts of social meaning. Normativity (including anything termed "legal") is therefore necessarily constructed and reconstructed across these discursive environments by virtue of the fact that agents circulate between them. Norms and the "systems" attributed to them are therefore not closed and stable but intrinsically open and contingent." ${ }^{29}$

This entails that in order to understand how ODR might function, the contingent expression of ODR must be studied. Furthermore, all aspects of the institutional context of ODR are potentially legally relevant. This means that a large number of considerations besides the ones discussed

28 Judgement of 18 March 2010, Joined Cases, Rosalba Alassini v Telecom Italia SpA (C-317/08), Filomena Califano $v$ Wind SpA (C-318/08), Lucia Anna Giorgia Iacono v Telecom Italia SpA (C-319/08) and Multiservice Srl v Telecom Italia SpA (C-320/08) Par 45, C-317/08, C-318/08, C-319/08 and C-320/08.

29 Davies, M. (2010) Legal Pluralism. In: Peter Cane and Herbert Kritzer (ed.). The Oxford Handbook of Empirical Legal Research. Oxford: Oxford University Press, p. 805-827, 823. 
in this article could (and should) be addressed in order to understand the relevant context for legal studies of ODR. ${ }^{30}$

The pluralistic theoretical view requires the researcher to pay attention to the procedural framework where consumer rights are (supposedly) made efficient. The relationship, and potential discrepancies, between an individual consumer right and a settled ODR procedure then inevitably become a focus of interest; e.g. does an ODR settlement mean that an individual consumer right has been enforced, and do possible transformations occur when a substantive legal act is situated in a specific institutional context?

Secondly, pluralism invites legal scholarship to consider how different disciplines/fields of law work together and how norms from different systems support or counteract each other. In this particular article, the focus of interest connects several fields of law, especially consumer protection law in relation to procedural law. In the examples discussed below, it must be considered that the ODR platform, enacted under Article 169 of TFEU, co-exists with mandatory consumer legislation and general (national) procedural principles.

Thirdly, the general understanding of pluralism strives to take into account all potentially legally relevant institutional factors. This includes the study of potential parallel systems for consumer protection legislation in the absence of a clear path for consumer cases to the supreme court (i.e. the CJEU). It has been argued in the ODR literature that paths to the general court system should not be hindered, but the question is whether there exists a functional route in the nitty gritty legal practice. The so-called "individual complaint journey" will in few instances lead to court and, in very few situations, find its way to the CJEU. "Ombudsprudence" has already been coined. ${ }^{31}$ Furthermore the institutional environment also invites the well explored discussion on how technology forms and transforms the consumer protection enforcement via various technological tools. ${ }^{32}$

Fourthly, pluralism could also be considered on a more formal level concerning the competence to issue legal norms relevant for ODR. EU member state competence regarding civil procedure, EU initiatives under

${ }^{30}$ Studies concerning the technological dimensions and their consequences of ODR included.

31 Stüner, M. (2014) ADR and Adjucation by State Courts: Competitors or Complements? Grundfragen, 3, pp. 122-128, 127. 
Article 169 of the TFEU, guiding procedural principles deriving from the European Convention of Human Rights (ECHR), and Article 47 of the Charter of Fundamental Rights (ECFR) are examples of how different legal institutions with different but overlapping competences all have normative influence over ODR. ${ }^{33}$

It is safe to assume that legal research rooted in legal pluralism, as it has been presented here, becomes very complicated. All relevant contexts cannot be addressed at once, and furthermore, the pluralistic perspectives deconstruct the idea that law can, in an exhaustive way, be studied from the position of the so-called legal insider. ${ }^{34}$ Instead, different perspectives need to complement each other in order to get a grasp of the complex "discursive elements" where

"[n]orms and the 'systems' attributed to them are therefore not closed and stable but intrinsically open and contingent." 35

From this theoretical point of departure, the present article continues to the more specific question of the role of the adversarial principle and the tendencies toward settlement.

\section{THE ADVERSARIAL PRINCIPLE WITHIN THE ODR FRAMEWORK}

It should first be noted that the ODR framework did not emanate from the field of procedural law but from Article 169 TFEU and the aim to promote the interests of consumers and ensure a high level of consumer protection.

Nevertheless, since all ODR schemes should be in accordance with the fundamental rights to an effective remedy and to a fair trial under Article 47 of ECFR, ODRs are also, of course, procedural in their nature. ${ }^{36}$

32 See, e.g. Carnerio, D. et al. (2012) Online dispute resolution: an artificial intelligence perspective. Artificial Intelligence Review, 41, pp. 211-240, Zeleznikow, J. (2017) Can Artificial Intelligence and Online Dispute Resolution Enhance Efficiency and Effectivness In Courts. International Journal For Court Administration, 8 (2), pp. 30-45 and Lodder, A. R. (2006) The Third Party and Beyond. An Analysis of the Different Parties, in particular the Fifth, Involved in Online Dispute Resolution. Information \& Communications Technology Law, 15 (2), pp. 143-155.

33 ODR Directive preamble $\S 26$, ADR Directive preamble $\S 45$.

34 Davies, M. (2010) Legal Pluralism. In: Peter Cane and Herbert Kritzer (ed.). The Oxford Handbook of Empirical Legal Research. Oxford: Oxford University Press, p. 805-827, 823, 816.

35 Op. cit., p. 823.

36 Regulation on consumer ODR, preamble $\S 26$, Directive on consumer ADR, preamble $\S 45$. 
Article 47 covers the scope of Article 6 and 13 of the ECHR. Although not spelled out in the article, the adversarial principle is held to be part of Article 6 of the ECHR. ${ }^{37}$

Ordinary civil court procedure is rooted in the adversarial principle, which includes the idea of rational negotiations between two parties that have equally strong arms at their disposal. The basic idea is that two parties put forth their interests, evidence, and arguments before a neutral third party in a rational way and also have the opportunity to criticize and debunk the argumentation of the other party. In this way, the parties, in total, have incentives to put forth all facts necessary for the neutral third party to make a ruling in accordance with the relevant substantive law. This, of course, is never the case in real court or ADR settings. The idea of two equal parties is in most situations an illusion, especially within the field of consumer litigation. ${ }^{38}$ In turn, this has amounted to political reforms in court systems during the last 40 years where the weaker party is supported in one way or another in order to ensure real equality of arms between the parties. The weaker party is supported by arms such as financial support to afford a legal counsel, substantive case management by the court, a relieved burden of proof, and special courts for consumer disputes in order to level the playing field in the proceedings.

Although reforms try to achieve "real" equality of arms, and thereby efficient adversarial proceedings, the adversarial model remains criticized. The main point of this criticism was summarized by Menkel-Meadow in the mid-1990s. ${ }^{39}$ Menkel-Meadow claimed that the binary positions intrinsic to the adversarial model polarize debate and tort the truth by leaving out information. The idea of oppositional presentation of facts only works when the actors involved in the process exhibit a genuine search for truth, which is something quite different than a genuine will to win a case. $^{40}$ The adversarial model, claims Menkel-Meadow, also simplifies complexity and obscures rather than clarifies.

It is not controversial to put forth that legal argumentation is situated in a complex contingent discursive environment, as described above. Thus,

37 Danelius, H. (2012) Mänskliga rättigheter $i$ europeisk praxis: En kommentar till Europakonventionen om de mänskliga rättigheterna. Stockholm: Norstedts Juridik, p. 246-247.

38 See, e.g. Galanter, M. (1975) Afterword: Explaining Litigation, Law E Society Review, 9 (2), p. 347-368, 363. See also Lindblom, PH. (2017) Progressive Procedure. Uppsala: Iustus, p. $155 f$.

39 Menkel-Meadow, C. (1996) The Trouble With the Adversary System in a Postmodern, Multicultural World. William and Mary Law Review, 38 (5), pp. 5-44, 13.

40 Op. cit., p. 13. 
the procedural order of formulating short claims and precise facts is delimiting the underlying conflict. To put it bluntly, the adversarial system lacks a genuine search for the complexities of reality.

Furthermore, the adversarial system is built upon the idea of positivist objectivity and neutrality and therefore also assumes the idea of common values among the parties involved. ${ }^{41}$ Objectivity and neutrality are furthermore the values that often are put forth as definitions of "independent and impartial" (in Article 47 ECFR and Article 6 ECHR). The idea of a positivist objectivity (in a legal context) has been widely criticized. ${ }^{42}$ Also the idea of a neutral third party has been heavily scrutinized, ${ }^{43}$ and add to this the diverse legal and societal conditions within the EU. In sum, there are several epistemological problems associated with the adversarial principle (as the best tool for finding the facts of a complex reality).

The idea of an "illusionary balance" between the parties is non-controversial to put forth, especially in a consumer litigation context. In fact, the illusionary balance can be regarded as the reason for this specific field of law to exist in the first place. The imbalance between the parties has led to different kinds of reforms in different kinds of proceedings in recent decades. It is common to call out the need for competent legal expertise (human or non-human) in order to bring equality of arms to the parties. ${ }^{44}$ However, it has been claimed by Menkel-Meadow that support via legal expertise brings skills concerning the procedure per se, and not arguments concerning the facts of the case. You win a case as a skilled lawyer and not as a lawyer who brings the relevant facts. But it should not be skill but argument, say the criticism here put forth. In sum, the idea of equality of arms misses the target, as it does not necessarily focus on the underlying conflict and therefore does not necessarily bring stronger enforcement of consumer rights to the table. ${ }^{45}$

${ }^{41}$ Op. cit., p. 8.

42 From e.g. both legal realists and from the Critical Legal Studies movement. See, e.g. Bladini, M. (2013) I objektivitetens sken: en kritisk granskning av objektivitetsideal, objektivitetsanspråk och legitimeringsstrategier i diskurser om dömande i brottmål. Göteborg: Makadam, p. 89ff.

43 See footnote 16 in Menkel-Meadow, C. (1996) The Trouble With the Adversary System in a Postmodern, Multicultural World. William and Mary Law Review, 38 (5), p. 5-44.

${ }^{44}$ See Article 47 of the ECFR.

45 See also Lewis concerning small case litigants without counsel and their difficulties in understanding what kind of evidence is needed, Lewis, P. (2007) Litigants in Person and Their Difficulties in Adducing Evidence: A Study of Small Claims in an English County Court. International Journal of Evidence E Proof, 11, p. 24-48. 
With this said, the present article does not advocate the abolishment of the adversarial principle, not least due to the lack of better options. ${ }^{46}$ Nevertheless, in line with the theoretical understanding presented above, the effects of the adversarial model must be taken into account when assessing how consumer legislation is made efficient through consumer litigation.

The institutional consequences of the adversarial principles within ODR schemes will now be discussed in more detail in relation to the two ODR entities mentioned above, i.e. the Swedish National Board for Consumer Disputes (Allmänna reklamationsnämnden, ARN) and the German General Consumer Arbitration Board, Center for Mediation (Allgemeine Verbraucher-schlichtungsstell. Zentrum für Schlichtung, AVZS).

\subsection{NATIONAL BOARD FOR CONSUMER DISPUTES (ARN)}

The Swedish ODR entity National Board for Consumer Disputes (ARN) has the manifest task of trying disputes that arise between consumers and business operators. ARN submits recommendations on how disputes should be resolved, e.g. it may decide/recommend that a product should be repaired by the company. ARN's recommendations are not binding, but a majority of Swedish companies follow them. ${ }^{47}$ The inquiry is free of charge for both the consumer and the business involved.

The activities of ARN are governed through legislation ("Instruction for ARN"), where it is stated that ARN is an ADR entity according to the ADR Directive. $^{48}$ The instruction also proclaims that ARN should fulfil the obligations that follow from the ODR regulation. However, so far, few cases are brought to ARN via the ODR platform. In 2017, 13 cases were initiated at ARN through the ODR platform (which can be compared with the 14,000 cases assessed yearly by ARN when national cases are included). ${ }^{49}$

${ }^{46}$ Although there are voices claiming that "EU is not, at heart, an adversarial culture, but seeks to build society based upon compromise and consensus" Hodges, C. (2016) Consumer Redress: Implementing the Vision. In: Pablo Cortés (ed.). The New Regulatory Framework for Consumer Dispute Resolution. Oxford: Oxford University Press, pp. 351-368, 367.

47 National Board for Consumer Disputes (Allmänna Reklamationsnämnden). (2017) Årsredovisning (Annual Report) 2017, pp. 7, 11 and 21.

48 Förordning (2015:739) med instruktion för Allmänna reklamationsnämnden'. (2015) (Instruction for ARN).

49 National Board for Consumer Disputes (Allmänna Reklamationsnämnden). (2017) Arsredovisning (Annual Report) 2017, pp. 7 and 11. 
At first sight, it seems as if ARN is neither adversarial nor friendly toward settlements. However, when looking closer, it becomes evident that the procedure of preparing the case before the Board follows a clear adversarial model. The procedure (that is always a written procedure) is initiated by a letter or an online form. If the matter is not rejected for formal reasons, ARN asks the company to comment on the consumer's claims. The consumer in turn has an opportunity to see and comment on the company's response. Both parties have the right to submit written evidence in the form of e.g. contracts or certificates of inspection.

The registration form instructs the consumer to describe a specific claim and in a clear way motivate the claim (and also provide evidence). After a formal review, the company is invited to respond. When the company has responded, the consumer has the opportunity to complement the case. At this stage, ARN could initiate a discussion in order to reach a settlement between the parties. If needed, there are also options for further written argumentation from the parties. ${ }^{50}$ If no settlement is reached, the case is assessed by the Board (at a meeting at which the parties are not present). ${ }^{51}$

The Board consists of a chairperson, who is a lawyer and has court experience, and two or four other members, who come from various consumer and trade organizations. The decisions of the Board are not formally binding for the company, but are nevertheless accepted in a majority of cases. For example, in 2017, 79 percent of the decisions were accepted by the company involved. ${ }^{52}$ The parties have no legal counsel but are advised to seek support from the public advisors in consumer disputes available online via the Swedish single point of Contents for Consumers.

\subsection{GENERAL CONSUMER ARBITRATION BOARD, CENTER FOR MEDIATION (AVZS)}

The German General Consumer Arbitration Board Center for Mediation (AVZS) is officially recognized by the Federal Office of Justice and is supported by the extrajudicial dispute resolution for consumers and entrepreneurs association. The task of the Arbitration Board is to mediate and settle disputes between companies and consumers in order to reach out-of-court

\footnotetext{
50 Instruction for ARN $\S \S 20-22$.

51 National Board for Consumer Disputes (Allmänna Reklamationsnämnden). (2017) Årsredovisning (Annual Report) 2017, p. 5.

52 Op. cit., p. 21.
} 
solutions. ${ }^{53}$ AVZS is governed by the German Act on Alternative Dispute Resolution in Consumer Matters, which implements the ADR Directive. ${ }^{54}$ The German legislation applies to both private and public ADR entities recognized under this Act. ${ }^{55}$ The AVZS received 2,125 applications in 2017, 101 of which came via the ODR platform. ${ }^{56}$

Even though AVZS is more focused on settlements compared with ARN, it nevertheless also follows an adversarial model. The procedure should only take into account the outspoken interests of the parties. ${ }^{57}$ It also follows from the AVZS rules of procedure that prior to the intervention by the arbitration board, the applicant must clearly formulate the contested claim against the respondent. ${ }^{58}$ According to $\S 4$ of the same document, it follows that the procedure is initiated by one of the parties which needs to describe the subject and interests at stake, and that the defendant thereafter is given an opportunity to respond. This phase can be conducted in writing, online, by telephone, or through direct personal conversation. The dispute resolution procedure ends by either a successful agreement or a declaration that the procedure has failed..$^{59}$

The mediations are performed by certified mediators according to mediation law or by full-time lawyers with judge qualifications. The mediators have the objective of working "impartially and independently", ${ }^{60}$ and may submit a settlement proposal to the consumers if there are no results in the initial negotiations for a settlement, yet the proposal is not binding on the parties. Following the ADR Directive and ODR Regulation, the AVZS Rules of Procedure state that the proposal must be based on the situation arising from the dispute settlement procedure, and that it should be aligned with applicable law and comply with the mandatory consumer protection laws. ${ }^{61}$

53 AVZS website (2019). [online] Available from: https://www.streitbeilegungsstelle.org/ueberuns/streitbeilegungsstelle/ [Accessed 11 mars 2019].

54 AVZS Rules of Procedure (Verfahrensordnung) $\S 8$.

55 Gesetz über die alternative Streitbeilegung in Verbrauchersachen - Verbraucher-streitbeilegungsgesetz (Act on Alternative Dispute Resolution in Consumer Matters), § 1 .

56 General Consumer Arbitration Board Center For Mediation Activity Report 2018, pp. 2, 4.

57 Op. cit., $\S 3(3)$.

58 Op. cit., $\S 4$ (2).

59 AVZS website (2019). [online] Available from https://www.streitbeilegungsstelle.org/dasverfahren/verfahrensordnung-ablauf/ [Accessed 11 March 2019]

60 AVZS website (2019). [online] Available from https://www.streitbeilegungsstelle.org/ueberuns/streitmittler/ [Accessed 11 March 2019].

$61 \quad$ AVZS Rules of Procedure (Verfahrensordnung) § 8 . 


\subsection{INITIAL REMARKS ON THE ROLE OF THE ADVERSARIAL PRINCIPLE FOR ARN AND AVZS}

Both ARN and AVZS comprise the features that the criticism of the adversarial model targets, namely that the situation is framed by the claim presented by the consumer, and that the process of formulating the facts of the case is done through a back-and-forth written proceeding where the third party (competent in consumer legislation) is passive. The Board, which represents the third neutral party, but also the party with the competence to safeguard consumer rights, becomes involved when the dispute has already been framed by the parties. An interesting question to ask is whether it is possible to safeguard consumer rights without safeguarding which facts enter the proceedings. The case law from the CJEU seems to, at least to some extent, point in the direction that national courts should be active also in, ex officio, investigating relevant facts in consumer cases. ${ }^{62}$

Compared with ARN, AVZS is more focused on finding a friendly resolution, and no decision is given by the ODR entity without consent from both parties. Nevertheless, if the dispute mediator has made a proposal to the parties to resolve the dispute under the rules of procedure, this proposal must be based on the facts resulting from the dispute resolution procedure. Furthermore, both ARN's and AVZS's websites inform the parties that the ODR entities are not consumer protection organizations and do not unilaterally represent interests. They offer no legal advice and therefore represent neither companies nor consumers. ${ }^{63}$ Instead, they serve as a neutral mediator between the parties. The paradoxical pluralistic mission, integral to ODR, here becomes obvious. ARN and AVZS are supposedly neutral third parties (adversarial model) and the same time actors obligated to uphold consumer protection (ADR Directive, §1). In the light of the ODR schemes described above, the view put forth by Menkel-Meadow that the adversarial principle tends to find its way into all kinds of legal procedure rings true, also for consumer redress ADR, online or not. The role of both acting as a neutral third party and defender of individual consumer rights is indeed challenging. And the situation will

62 See Section 2 above.

${ }^{63}$ AVZS website (2019). [online] Available from https://www.verbraucher-schlichter.de/ueberuns/verbraucherschlichtungsstelle [Accessed 11 March 2019]. The same principle is noted on the ARN's website: https://www.arn.se/ [Accessed 11 March 2019]. 
become even more complex when we add the tendencies toward settlements.

\section{TENDENCIES TOWARD SETTLEMENT}

The trend toward an increasing number of settlements is not only a trend within ADR (including ODR), but also within all kinds of civil procedure. ${ }^{64}$ Settlements promise possibilities to achieve quick solutions, which is held as a value on its own regard. ${ }^{65}$ Nevertheless, similar to the adversarial principle, settlements, too, have institutional and procedural consequences that have been highlighted in the legal literature.

Already in the 1980s, Owen Fiss formulated a quite elegant critique of settlements. The critique implicates that settlements are counterproductive in relation to the substantial law that the case concerns. The parties bypass the consumer litigation and instead agree on a sum of money to be paid in compensation, an agreement that replaces concrete application of the law. Of course, the settlement negotiations are not unrelated to the substantial law, but the point is that the process becomes more about assessment of e.g. risks, time delay, procedural costs etc. and less about finding facts in the case and matching them with substantive consumer rights. ${ }^{66}$

Within the field of ODR, Eidenmüller and Engel have warned against "false settlements". They argue that

"mandatory consumer protection rights attempt to correct market failure.

Hence, enforcing these rights should not be returned to the market." 67

64 "Settlement euphoria". Eidenmüller, H. and Engel, M. (2014) Against False Settlement: Designing Efficient Consumer Rights Enforcement Systems in Europe. Ohio State Journal on Dispute Resolution, 29 (2), pp. 261-298, 263.

65 Cortés, P. (2014) Online Dispute Resolutions Services: A Selected Number of Case Studies. Computer and Telecommunications Law Review, 6, pp. 172-178, 172 and Cortés, P. (2016) The New Landscape of Consumer Redress: The European Directive on Consumer Alternative Dispute Resolution and the Regulation on Online Dispute Resolution. In: Pablo Cortés (ed.). The New Regulatory Framework for Consumer Dispute Resolution. Oxford: Oxford University Press, pp. 17-41, 35.

66 See Wagner, G. (2014) Private Law Enforcement Through ADR: Wonder Drug Or Snake Oil. Common Market Law Review, 51, pp. 165-194, 176. See also Eidenmüller, H. and Engel, M. (2014) Against False Settlement: Designing Efficient Consumer Rights Enforcement Systems in Europe. Ohio State Journal on Dispute Resolution, 29 (2), pp. 261-298, 281 and Weiss, R. (2006) Some Economic Musings on Cybersettle. University of Toledo Law Review, 38, pp. 89-99, 95ff.

67 Eidenmüller, H. and Engel, M. (2014) Against False Settlement: Designing Efficient Consumer Rights Enforcement Systems in Europe. Ohio State Journal on Dispute Resolution, 29 (2), pp. 261-298, 263. 
In addition to this, there are concerns that 300 ODR entities will result in a fragmentation of decisions, which will make it difficult to uphold consistent consumer law application throughout the EU. ${ }^{68}$ De Paolo and Canessa highlight that lawyers and parties tend to take the path of least resistance. ${ }^{69}$ If consumer rights are to be protected, they need to be accompanied with smooth institutional structures. However, dealing with cross-border cases, the situation is often quite the opposite. Few consumers will consider suing a company for a faulty object worth 100 euro in their own city, and even less so if the company is seated in another country. ${ }^{70}$ Furthermore, very few consumers will risk a proposed 50/50 settlement when faced with the risk of having to engage in lengthy process with the potential outcome of getting nothing. The ADR Directive and ODR Regulation are clear on the point that ODR should not deny the consumer's right of access to court. However, Eidenmüller and Engel point out that it very unlikely that a consumer will continue to court if an "expert" (the $A D R$ Board/mediator) already has stated that the consumer has no case. The formal right of "access to court" is one thing; the institutional potential to make that right effective is another. ${ }^{71}$

Consumer legislation, formulated as individual rights, is often mandatory in the sense that the consumer is prohibited to refrain from the exercising the right. The logic behind this is that consumer protection legislation is in place in order to defend consumers from the influence of business owners. Opening up for individuals to refrain from their right would reduce the level of protection. In relation to this logic within the substantive law, it is a bit paradoxical that individual consumers, taking part of the ODR procedure, are trusted to accept settlements and decide which facts and arguments to bring to the table, when they at the same time are not, in many regards, deemed suitable to negotiate the terms of a consumer purchase. ${ }^{72}$ With this being said, consumer rights are not

68 See Wagner, G. (2014) Private Law Enforcement Through ADR: Wonder Drug Or Snake Oil. Common Market Law Review, 51, pp. 165-194, 171ff.

${ }^{69}$ De Paolo, G. and Canessa, R. (2016) New Trends for ADR in the European Union. In: Pablo Cortés (ed.). The New Regulatory Framework For Consumer Dispute Resolution. Oxford: Oxford University Press, pp. 407-426, 425.

${ }^{70}$ Eidenmüller, H. and Engel, M. (2014) Against False Settlement: Designing Efficient Consumer Rights Enforcement Systems in Europe. Ohio State Journal on Dispute Resolution, 29 (2), pp. 261-298, 268.

${ }^{71}$ Op. cit., p. 293.

72 Although this is exactly the point made by CJEU in the case law cited above, namely that the court ex officio should provide consumers with information on which facts to bring to the case. 
the only dimensions of conflict of importance to consumers. ${ }^{73}$ The point being made here is merely that the paradoxical dimension of consumer redress, where consumers are autonomous and not autonomous at the same time, is part of the institutional landscape.

So far, a very small share of consumer-company conflict reaches the ODR framework. The European Commission has been monitoring and gathering information on ODR entities since the launch in 2016. In a report from 2017, an analysis was made of a complete dataset related to all complaints logged on the platform from 15 February 2016 to 15 February 2017. The analysis focused solely on complaints that were generated within the platform's workflow and did not take into consideration complaints received by ADR entities directly, i.e. outside the platform. ${ }^{74}$

During the 12 months monitored by the Commission, some 1.9 million people visited the platform and more than 24,000 complaints were submitted on the platform in its first year of operation. ${ }^{75}$ However, 85 percent of the complaints were automatically closed within 30 days of submission due to the deadline for the consumer and business to agree on a competent ADR body. In order to understand the significance of these data and evaluate the interest of companies in ADR procedures, the Commission carried out a specific survey to get feedback from consumers whose cases were automatically closed. The survey revealed that, although a large number of businesses did not follow through using the ODR platform, 40 percent of consumers who submitted a complaint on the ODR platform that was automatically closed after 30 days had been contacted directly by the company to solve the problem without any further progression of the complaint on the platform. Hence, the ODR framework may lead to more case resolutions than the statistics show. ${ }^{76}$ Nine percent of the complaints submitted via the ODR platform were not automatically

73 See Hodges, C. (2016) Consumer Redress: Implementing the Vision. In: Pablo Cortés (ed.). The New Regulatory Framework for Consumer Dispute Resolution. Oxford: Oxford University Press, pp. 351-368, 358.

74 European Commission. (2017) Report from the Commission to the European Parliament and the Council on the functioning of the European Online Dispute Resolution platform established under Regulation (EU) No 524/2013 on online dispute resolution for consumer disputes COM(2017) 744 final', (2017).

75 Op. cit., p. 4.

76 There are also technical reasons for the businesses' lack of responsiveness on the platform. For example, when a complaint is against a business is submitted for the first time and the business is not yet registered on the platform, the automatic notification may reach an incorrect email address. Other reasons could be that the origin of the notification message is unclear to the business or that the notification ends up in the businesses' email spam folder and remains unread. Op. cit., p. 6. 
closed by the system but were refused by the company. Furthermore, in many of these cases, the respective businesses indicated that they made direct contact with the consumer and solved the issue or were planning to do so. For 4 percent of the submitted complaints, the data showed that both parties had used the possibility to withdraw from the procedure before their agreement to use a specific ADR body. ${ }^{77}$

Only 2 percent of the complaints were submitted to a specific ADR body. In around half of these cases, the ADR bodies refused to deal with the case on procedural grounds such as lack of competence or the consumer's failure to attempt to contact the business first. In some instances, either consumers or businesses withdrew from the procedure before it was completed. In the end, ADR procedure reached a final outcome in less than 1 percent of the 24,000 cases submitted via the platform, i.e. a couple of hundred cases. $^{78}$

On the other hand, the Commission states that 44 percent of the submitted cases were settled bilaterally outside the platform. ${ }^{79}$ All in all, this means that a large part of the cases processed via the ODR platform reach settlements. This also means that a very limited share of consumer-company conflicts result in the application of consumer legislation on facts of the case, in a court application sense.

Let us now consider settlement more closely in relation to the two ODR entity examples.

\subsection{THE NATIONAL BOARD FOR CONSUMER DISPUTES (ARN)}

ARN is not an ODR designed to settle cases. Instead, as mentioned above, the main route of the procedure is for the Board to finalize a written recommendation. Nevertheless, current trends toward efficiency have led to reforms, and since 2016 ARN has been obliged to make efforts in order for the parties to reach a settlement. According to 33 and $\S 22$ of the instruction for ARN, the Board should try to encourage a settlement between the parties. ${ }^{80}$

A report from the parliamentary ombudsmen in Sweden (JO) states that ARN, during a trial period conducted conciliation talks by telephone

Ibid.

78 Op. cit., p. 7.

79 Ibid.

80 Förordning (2015:739) med instruktion för Allmänna reklamationsnämnden'. (2015) (Instruction for ARN) $3 \S$ and $22 \S$. 
(in order to reach settlements) and measured among other things the time they spent on the conversation. During the evaluation, it was found that the ARN staff had managed to reconcile the parties in a majority of cases, but that the conciliation talks took a lot of time. The staff were therefore advised not to raise the issue of conciliation in all cases, but only in cases where time could be saved. ${ }^{81}$ The reason for considering a settlement could therefore be said to concern cost efficiency for ARN, not other normative values connected to consumer protection. ${ }^{82}$ Hence, the reason for settlements concerns the efficiency of ARN as an organization trying to increase its efficiency in achieving resolutions. The possible distinction between a settlement and an assessment of facts under relevant (mandatory) consumer legislation was not discussed in the report. In 2017, 22 percent of the cases brought to ARN reached a settlement and therefore did not end up in a written decision from the Board. This should be compared with the 37 percent of the cases that actually resulted in a decision by the Board. ${ }^{83}$

In sum, although the basic design of ARN points toward a decision by the Board, a fifth of the cases are resolved through settlements. This is a relatively high number considering that only 37 percent of the cases end up with a substantive decision.

\subsection{GENERAL CONSUMER ARBITRATION BOARD, CENTER FOR MEDIATION (AVZS)}

As mentioned above, it follows from the AVZS website that it is not a consumer protection organization. Furthermore, AVZS offers no legal advice and therefore represents neither companies nor consumers. Instead, it serves as a neutral mediator between the parties. Nevertheless, if the mediation does not lead to an amicable solution, the Board submits an arbitration proposal accompanied with reasons for the proposal.

81 Justitieombudsmannen, 'Dnr 6398-2017 - Inspektion av Allmänna reklamations nämnden (ARN) den 23-24 oktober 2017 (Parlimentary Ombudsmen, Inspection of ARN 23-24 oktober 2017), p. 4.

82 See National Board for Consumer Disputes (Allmänna Reklamationsnämnden). (2017) Årstedovisning (Annual Report) 2017, p. 10.

83 Förordning (2015:739) med instruktion för Allmänna reklamationsnämnden' (2015). (Instruction for ARN) $3 \S$ and $22 \S$. National Board for Consumer Disputes (Allmänna Reklamationsnämnden). (2017) Årsredovisning (Annual Report) 2017, p. 6 (when cases where the company has not responded are included, this number rises to 47 percent for the year 2017, p. 15). 
The Board must also inform the parties of the possibility of not accepting the deal and instead having the option to turn to a court. ${ }^{84}$

According to the activity report for 2018, 1,993 of 2,125 cases were finished at AVZS. ${ }^{85}$ All of these cases were not settled since also cases that were withdrawn were counted as finished. Overall, 1,376 cases were unsuccessful in the sense that no agreement was reached between the parties. Of these, 1,171 were unsuccessful in this way because the defendant did not get involved in the procedure. Furthermore, 197 applications were withdrawn by the applicant. ${ }^{86}$ When excluding the number of rejected cases (396), the agreement rate for 2017 ends up being 13.84 percent, which means that 221 cases were settled. ${ }^{87}$ There is no information in the report concerning the underlying reasons in order for the parties to reach a settlement.

\subsection{GENERAL CONSIDERATIONS CONCERNING THE TENDENCIES TOWARD SETTLEMENT}

The statistics from the Commission report and the figures from ARN and AVZS paint a picture of settlements being very common. Also for ARN, a body where the main path of procedure does not lead to settlements, they are still very common. Although there are no statistics from ARN, AVZS, and the Commission, it is not very farfetched to assume, following Weiss, Wagner, Eidenmüller and Engel, that a large share of the settlements are not based on consumer regulation considerations, but rather on considerations of costs, risks, and quick resolutions to the conflicts at hand. ${ }^{88}$ The examples from ARN also indicate that the ODR entity involves a cost benefit analysis concerning when to pursue a settlement and when not to. The normative difference between a settlement and an assessment of the facts in a case does not seem to be an issue of concern. The two types of resolutions are treated as interchangeable. The lack of discussion or distinction between a settlement, a reasoned proposal, and an assessment of the facts in a case,

\footnotetext{
84 AVZS Rules of Procedure (Verfahrensordnung) § 8 (3).

${ }^{85}$ General Consumer Arbitration Board Center For Mediation Activity Report 2018, p. 2.

${ }^{86}$ Op. cit., p. 7.

87 Op. cit., p. 8.

88 Weiss, R. (2006) Some Economic Musings on Cybersettle, University of Toledo Law Review, 38, p. 89-99, Wagner, G. (2014) Private Law Enforcement Through ADR: Wonder Drug Or Snake Oil. Common Market Law Review, 51, pp. 165-194 and Eidenmüller, H. \& Engel, M. (2014) Against False Settlement: Designing Efficient Consumer Rights Enforcement Systems in Europe. Ohio State Journal on Dispute Resolution, 29 (2), pp. 261-298.
} 
in the Commission report, and in the information provided by ARN or AVZS is interesting considering that resolving a conflict to avoid time-delay or to avert risks is something quite different than applying a legal right.

\section{PROCEDURAL TRANSFORMATION WITHIN ODR SCHEMES}

This article has focused on two specific procedural considerations regarding ODR: the adversarial principle and tendencies toward settlements. The reasoning is rooted in the idea that in order to understand the consequences of the ADR and ODR initiatives, we need to understand the procedural mechanisms that contribute to the enforcement of the legal norms at stake.

An obvious starting point for this discussion is to put forth that to settle is to do something other than enforce a consumer right. There is quite a different normative process involved. Instead of matching substantive norms to facts, the parties are involved in a negotiation based on economic rationale. However, the distinction between different kinds of resolutions is not visible in the official reports concerning ODR. As already mentioned, the ODR platform has the twofold objective of promoting both consumer protection and the internal market. A distinction between resolving a case based on the application of legal rights, and resolving a case based on the broader considerations involved in settlements is central to the objective of promoting consumer protection, but it is not as relevant in relation the growth of the EU economy. Since consumer transactions add up to a large part of the EU's gross domestic product, there is considerable economic interest in making the consumer market as efficient as possible. The lack of distinction between applications of norms and resolutions on other grounds makes sense only in relation the objective of the ODR framework to promote cross-border trade. Conflicts need to be resolved for the market to function, but the normative basis for such resolutions is not that important. The economic efficiency is calculated at an aggregated level, which is quite an opposite starting point compared with individual legal rights, and the prime aim is resolutions. From this perspective, the consumers become a mass, a collective, that is weighed against an abstract economic interest of the companies to strike a balance with positive effects on the internal market. The possibilities to find efficient consideration toward consumers, on an aggregated scale, is further 
strengthened by the possibilities to access data due to the digital dimension of ODR ${ }^{89}$ Or as expressed by Eidenmüller and Engel:

"mandatory consumer protection rights attempt to correct market failure."

In other words, the focus on settlements (and the adversarial model) could be said to build a system around economic rationale in order to support the system as such making the objective of economic growth primary and the objective of enforcing (individual) consumer rights secondary. From what seems (at least at a first glance) to be the opposite perspective, the signals from the CJEU, i.e. that court officials around EU should take active steps to ensure individual consumer rights, paint quite a different picture.

Furthermore, the ADR Directive Article 11 stresses that there must be no infringements of mandatory consumer law. These concerns have led to raised voices for the need for individual assessments based on an adversarial model that ensures access to courts in a fair trial where the parties have equal arms. ${ }^{91}$ Nevertheless, if ODR is seen as something that becomes when legal decisions are made (rather than as a fixed field of law open to doctrinal studies), then it should be considered that in many cases, no resolutions seem to take place at all. After all, the statistics show that less than 1 percent of the cases submitted to an ODR platform reach some sort of a substantive assessment. In this institutional landscape (a landscape of an almost non-existent formal consumer redress), there are calls for quick and flexible routes to ensure just conflict resolutions to consumers. This is where settlements enter the stage. But once again, quite interestingly, the potential problems arising from too many settlements are leading to a renewed call for more strict adversarial models of conflict resolution, as the adversarial process is seen as strengthening access to justice. ${ }^{92}$ Therefore, considering the risk for settlements on non-legitimate grounds, adversarial models are called for to safeguard

89 Concerning this, see Weiss, R. (2006) Some Economic Musings on Cybersettle. University of Toledo Law Review, 38, p. 89-99, 96 and Cortés, P. (2017b) The Online Court: Filling the Gaps of the Civil Justice System? Civil Justice Quarterly, 36 (1), pp. 109-126, 173.

90 Eidenmüller, H. \& Engel, M. (2014) Against False Settlement: Designing Efficient Consumer Rights Enforcement Systems in Europe. Ohio State Journal on Dispute Resolution, 29 (2), pp. 261-298, 263.

91 See, e.g. Eidenmüller, H. \& Engel, M. (2014) Against False Settlement: Designing Efficient Consumer Rights Enforcement Systems in Europe. Ohio State Journal on Dispute Resolution, 29 (2), pp. 261-298, 269.

92 Ibid. 
individual rights. And, vice versa, when the adversarial model makes processes slow and complicated, settlements offer the necessary quick and flexible routes to ensure just conflict resolutions to consumers. ${ }^{93}$ In this way, the adversarial model and settlements promise solutions to each other's problems in a paradoxical manner.

This article concludes in this contradictory notion with no clear answers on how to strike the best balance for ODR schemes. Taking a pluralistic approach, it is clear that the complex reality of consumer redress gives rise to different kinds of problems at different levels depending on how we go about conflict resolution. Consumer redress through the ODR platform will transform consumer conflicts (as all legal institutions do). This transformation is an integral part of law. "Resolution" is not the same in a settlement compared to an application of norms to facts. Furthermore, a settlement based on an individual assessment is not the same as a settlement where the mediator has access to aggregated data on typical consumer behavior. Lastly, a presentation of a case channeled through an adversarial model is not the same as a presentation of a case channeled through ex officio action by an investigating authority. Further research in this field is called for in order to understand the special and varying implications of procedural principles surrounding consumer protection within ODR.

\section{LIST OF REFERENCES}

[1] ARN. (2019) [online] Available from: https://www.arn.se/ [Accessed 11 March 2019].

[2] AVZS. (2019) [online] Available from: https://www.verbraucher-schlichter.de/ueberuns/verbraucherschlichtungsstelle [Accessed 11 March 2019].

[3] Bladini, M. (2013) I objektivitetens sken: en kritisk granskning av objektivitetsideal, objektivitetsanspråk och legitimeringsstrategier i diskurser om dömande ibrottmål. Göteborg: Makadam.

[4] Carnerio, D. et al. (2012) Online dispute resolution: an artificial intelligence perspective. Artificial Intelligence Review, 41.

[5] Cortés, P. (2014) Online Dispute Resolutions Services: A Selected Number of Case Studies. Computer and Telecommunications Law Review, 6.

93 Cortés, P. (2016) The New Landscape of Consumer Redress: The European Directive on Consumer Alternative Dispute Resolution and the Regulation on Online Dispute Resolution. In: Pablo Cortés (ed.). The New Regulatory Framework for Consumer Dispute Resolution. Oxford: Oxford University Press, pp. 17-41, 3. 
[6] Cortés, P. (2016) The New Landscape of Consumer Redress: The European Directive on Consumer Alternative Dispute Resolution and the Regulation on Online Dispute Resolution. In: Pablo Cortés (ed.). The New Regulatory Framework for Consumer Dispute Resolution. Oxford: Oxford University Press.

[7] Cortés, P. (2017a) The Law of Consumer Redress in an Evolving Digital Market: Upgrading from Alternative to Online Dispute Resolution. Cambridge: Cambridge University Press.

[8] Cortés, P. (2017b) The Online Court: Filling the Gaps of the Civil Justice System? Civil Justice Quarterly, 36 (1).

[9] Danelius, H. (2012) Mänskliga rättigheter i europeisk praxis: En kommentar till Europakonventionen om de mänskliga rättigheterna. Stockholm: Norstedts Juridik.

[10] Davies, M. (2010) Legal Pluralism. In: Peter Cane and Herbert Kritzer (ed.). The Oxford Handbook of Empirical Legal Research. Oxford: Oxford University Press.

[11] De Paolo, G. and Canessa, R. (2016) New Trends for ADR in the European Union. In: Pablo Cortés (ed.). The New Regulatory Framework For Consumer Dispute Resolution. Oxford: Oxford University Press.

[12] Directive 2013/11/EU of the European Parliament and of the Council of 21 May 2013 on alternative dispute resolution for consumer disputes and amending Regulation (EC) No 2006/2004 and Directive 2009/22/EC.

[13] Eidenmüller, H. \& Engel, M. (2014) Against False Settlement: Designing Efficient Consumer Rights Enforcement Systems in Europe. Ohio State Journal on Dispute Resolution, 29 (2).

[14] European Commission. (2011) Commission Staff Working Paper Impact Assessment Accompanying the document Proposal for a Directive of the European Parliament and of the Council on Alternative Dispute Resolution for consumer disputes (Directive on consumer ADR) and Proposal for a Regulation of the European Parliament and of the Council on Online Dispute Resolution for consumer disputes (Regulation on consumer ODR). SEC(2011) 1408 final.

[15] European Commission. (2012) Communication From The Commission To The European Parliament, The Council, The Economic and Social Committee and the Committee of the Regions: A European Consumer Agenda-Boosting confidence and growth. $\operatorname{COM}(2012) 225$ final.

[16] European Commission. (2017) Report From The Commission to The European Parliament and The Council on the functioning of the European Online Dispute 
Resolution platform established under Regulation (EU) No 524/2013 on online dispute resolution for consumer disputes. COM(2017) 744 final.

[17] Förordning (2015:739) med instruktion för Allmänna reklamationsnämnden'. (2015) (Instruction for ARN).

[18] Galanter, M. (1975) Afterword: Explaining Litigation. Law \& Society Review, 9 (2).

[19] General Consumer Arbitration Board Center for Mediation (Allgemeine Verbraucher-schlichtungsstelle Zentrum für Schlichtung) Activity report (2018).

[20] Gesetz über die alternative Streitbeilegung in Verbrauchersachen- Verbraucher-streitbeilegungsgesetz (Act on Alternative Dispute Resolution in Consumer Matters).

[21] Hodges, C. (2016) Consumer Redress: Implementing the Vision. In: Cortés, Pablo (ed.). The New Regulatory Framework for Consumer Dispute Resolution. Oxford: Oxford University Press.

[22] Judgement of 18 March 2010, Joined Cases, Rosalba Alassini v Telecom Italia SpA (C-317/08), Filomena Califano $v$ Wind SpA (C-318/08), Lucia Anna Giorgia Iacono v Telecom Italia SpA (C 319/08) and Multiservice Srl v Telecom Italia SpA (C-320/08) Par 45, C-317/08, C-318/08, C 319/08 and C-320/08.

[23] Judgement of 26 October 2006, Mostaza Claro v Centro Móvil Milenium SL, C-168/05, ECLI:EU:C:2006:675.

[24] Judgement of 27 June 2000, Joined Cases, Océano Grupo Editorial SA v Roció Murciano Quintero and Salvat Editores SA v José M. Sánchez Alcón Prades and Others, C 240/98 to C-244/98, ECLI:EU:C:2000:346.

[25] Judgement of 4 June 2009, Pannon GSM Zrt. v Erzsébet Sustikné Györfi, C-243/08, ECLI:EU:C:2009:350.

[26] Judgement of 3 October 2013, Soledad Duarte Hueros v Autociba SA och Automóviles Citroën España SA, C-32/12, ECLI:EU:C:2013:637.

[27] Judgement of 6 July 2010, VB Pénzügyi Lizing Zrt. v Ferenc Schneider, C-137/08, ECLI:EU:C:2010:659.

[28] Justitieombudsmannen (Parlimentary Ombudsmen). (2017) 'Dnr 6398-2017 - Inspektion av Allmänna reklamationsnämnden (ARN) den 23-24 oktober 2017 (Inspection of ARN 23-24 oktober 2017).

[29] Lewis, P. (2007) Litigants in Person and Their Difficulties in Adducing Evidence: A Study of Small Claims in an English County Court. International Journal of Evidence \& Proof, 11.

[30] Lindblom, PH. (2017) Progressive Procedure. Uppsala: Iustus. 
[31] Lodder, A. R. (2006) The Third Party and Beyond. An Analysis of the Different Parties, in particular the Fifth, Involved in Online Dispute Resolution. Information $\mathcal{E}$ Communications Technology Law, 15 (2).

[32] Menkel-Meadow, C. (1996) The Trouble With the Adversary System in a Postmodern, Multicultural World. William and Mary Law Review, 38 (5).

[33] National Board for Consumer Disputes (Allmänna Reklamationsnämnden). (2017) Årsredovisning (Annual Report) 2017.

[34] Regulation (EU) No 524/2013 of the European Parliament and of the Council of 21 May 2013 on online dispute resolution for consumer disputes and amending Regulation (EC) No 2006/2004 and Directive 2009/22/EC.

[35] Rosenfeld, M. (1998) Just interpretations: Law between ethics and politics. Santa Monica: University of California Press, 1998.

[36] Schlote, J. A. (2017) Polycentrism and Democracy in Internet Governance. In: Uta Kohl (ed.). The Net and the Nation State. Cambridge: Cambridge University Press.

[37] Stüner, M. (2014) ADR and Adjucation by State Courts: Competitors or Complements? Grundfragen, 3.

[38] Wagner, G. (2014) Private Law Enforcement Through ADR: Wonder Drug Or Snake Oil. Common Market Law Review, 51.

[39] Wallerman, A. (2019) Manoeuvring Procedural Autonomy In Sweden: Is Materielle Prozessleitung the Answer? In: Anna Nylund and Bart Krans (ed.). Procedural autonomy: Room for manoeuvre? Cambridge: Intersentia [forthcoming].

[40] Weiss, R. (2006) Some Economic Musings on Cybersettle. University of Toledo Law Review, 38.

[41] Zeleznikow, J. (2017) Can Artificial Intelligence And Online Dispute Resolution Enhance Efficiency And Effectivness In Courts. International Journal For Court Administration, 8 (2). 